\title{
Ontogenetic comparison of larvae and juveniles of Diaphus garmani and Benthosema pterotum (Myctophidae, Pisces) collected from Korea
}

\author{
Hye-Lyang Lee ${ }^{1}$, Jin-Koo Kim ${ }^{1 *}$ (D), Hyo-Jae Yu ${ }^{1,2}$ and Jung-Nyun Kim²
}

\begin{abstract}
During June 2017, we collected two postflexion larvae (6.01 and $7.56 \mathrm{~mm}$ in standard length [SL]) and two juveniles (7.72 and $9.62 \mathrm{~mm} \mathrm{SL)} \mathrm{belonging} \mathrm{to} \mathrm{Myctophidae} \mathrm{in} \mathrm{the} \mathrm{waters} \mathrm{of} \mathrm{Jejudo} \mathrm{Island.} \mathrm{Those} \mathrm{four} \mathrm{individuals} \mathrm{were}$ identified as Diaphus garmani, which had not been reported in Korea. They were distinguished from Benthosema pterotum by melanophores in the abdominal cavity (absent in D. garmani vs. present in B. pterotum) and the development of photophores (developed in D. garmani vs. rudimentary in B. pterotum) when shorter than $10.0 \mathrm{~mm}$ $\mathrm{SL}$. Analysis of $16 \mathrm{~S}$ rRNA sequences showed that the sequences of four individuals matched those of adult $D$. garmani (Kimura 2-parameter distance: $0.6-0.8 \%$ ). This is the first record of larvae and juveniles of D. garmani in Korean waters, and we propose a new Korean name, Gar-ma-ni-sat-bi-neul-chi.
\end{abstract}

Keywords: Diaphus garmani, Benthosema pterotum, Larvae, Juvenile, Myctophidae, New record, 16S rRNA, Korea

\section{Background}

The family Myctophidae in the order Myctophiformes contains 251 species in 33 genera worldwide (Fricke et al. 2019), of which four species in three genera (Benthosema pterotum, Myctophum asperum, Myctophum affine, and Notoscopelus japonicus) occur in Korean waters (MABIK 2019; Park et al. 2019). The lanternfishes (Myctophidae) are mesopelagic fish that undertake diel vertical migration as a unique environmental adaptation (Ozawa 1986; Mini and James 1990; Moser and Ahlstrom 1996; Watanabe et al. 1999). They have a compressed body shape, large mouth, rows of small teeth, a swim bladder, bioluminescent photophores, and adipose fins (Nafpaktitis 1978, 1982, Nafpaktitis et al. 1995; Paxton et al. 1984; Martin et al. 2018).

\footnotetext{
* Correspondence: taengko@hanmail.net

'Department of Marine Biology, Pukyong National University, Busan 48513, Korea

Full list of author information is available at the end of the article
}

The genus Diaphus in the family Myctophidae comprises 77 recognized species worldwide (Nelson et al. 2016; Froese and Pauly 2019) and has not been reported in Korea. The species in the genus Diaphus are classified into the Diaphus A and B groups depending on the presence and absence, respectively, of photophores on the suborbital organ (So), mouth morphology of early larvae, position of the anus, expression of melanophores and photophores, and timing of metamorphosis(Javadzadeh et al. 2012). Of which, Diaphus garmani is a small fish ( 60 $\mathrm{mm}$ total length) belonging to the Diaphus B group and thus lacks photophores on the So (Nafpaktitis 1978; Nelson et al. 2016). Some studies of Diaphus have examined its early life history (Bineesh et al. 2010) and the first recorded species (Sassa et al. 2003). In Korea, studies of mesopelagic fish have examined the early life history of Maurolicus muelleri (Kim and Yoo 1999; Kim et al. 2007) and a new record for Sigmops gracilis (Lee and Kim 2013).

As the Myctophidae larvae collected in this study had similar morphological features to those of Benthosema

(c) The Author(s). 2020 Open Access This article is licensed under a Creative Commons Attribution 4.0 International License, which permits use, sharing, adaptation, distribution and reproduction in any medium or format, as long as you give

appropriate credit to the original author(s) and the source, provide a link to the Creative Commons licence, and indicate if changes were made. The images or other third party material in this article are included in the article's Creative Commons licence, unless indicated otherwise in a credit line to the material. If material is not included in the article's Creative Commons licence and your intended use is not permitted by statutory regulation or exceeds the permitted use, you will need to obtain permission directly from the copyright holder. To view a copy of this licence, visit http://creativecommons.org/licenses/by/4.0/ 
pterotum, we confirmed the correctness of species identification by using 16S rRNA sequences. Afterward, indepth morphological data related to ontogenetic features of these two species were compared with each other, which are barely distinguishable at the larval stage.

\section{Methods}

\section{Sampling}

Four larval specimens (PKUI 618-621) of Diaphus garmani were collected from the southern Jejudo Island in June 2017 by a research vessel from the National Institute of Fisheries Science using a bongo net (mouth diameter $80 \mathrm{~cm}$; mesh size $500 \mu \mathrm{m}$ ). The collected specimens were immediately fixed in $5 \%$ formalin for $1 \mathrm{~h}$ on the vessel and then washed before being placed in a $1 \mathrm{~L}$ polyethylene container, where they were fixed in $99 \%$ alcohol. Four Benthosema pterotum larvae (PKUI 614-617) were also collected from the western Jejudo Island to the East Sea between July and December 2018 (Fig. 1). After the study, the specimens were deposited at Ichthyoplankton Laboratory of Pukyong National University (PKUI).

\section{Morphological analysis}

The larvae were identified according to their morphological characteristics and photophore features observed, following the methods described by Richards (2006), Okiyama (2014), Nakabo (2013), and Martin et al.

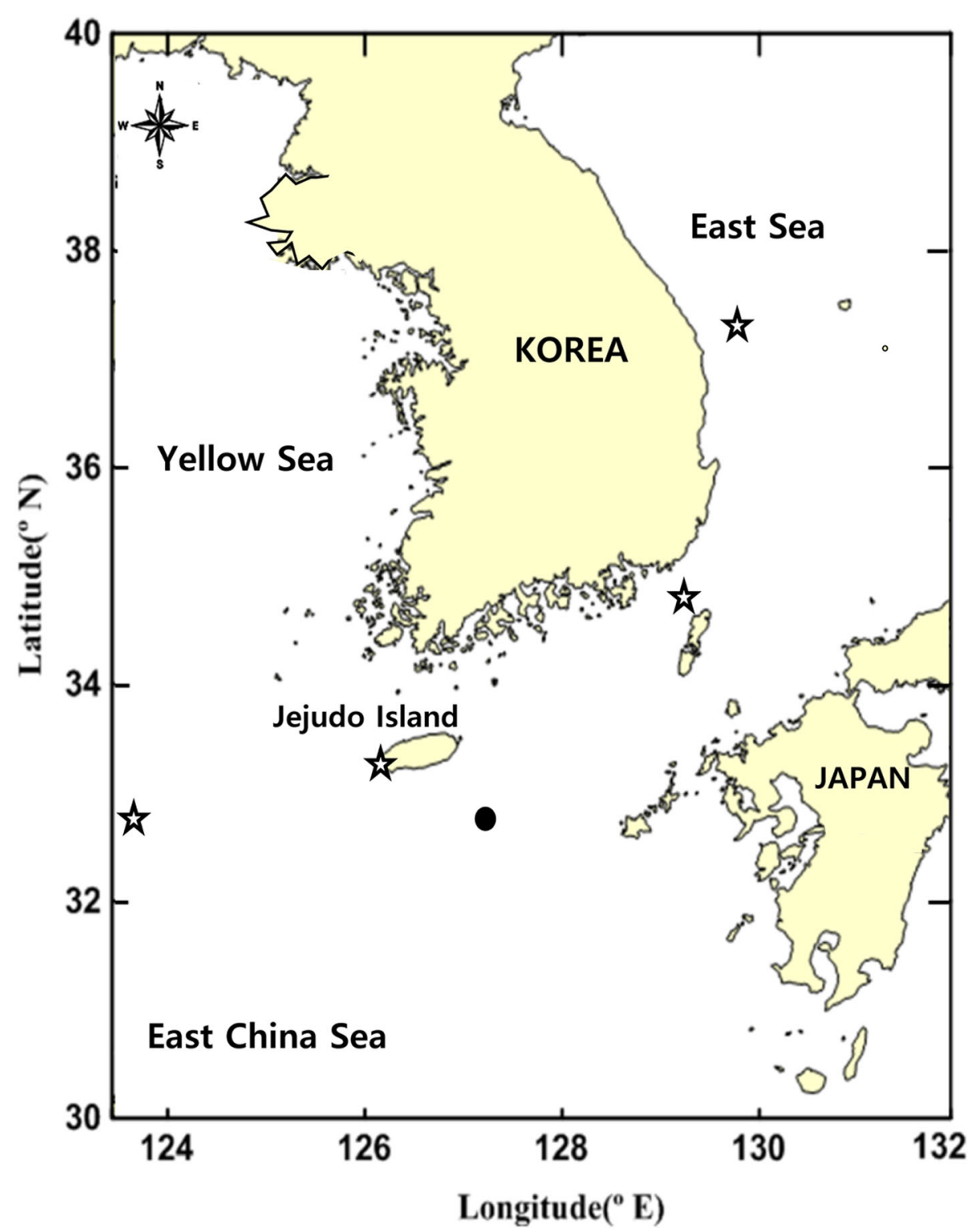

Fig. 1 Map showing the sampling sites of Diaphus garmani larvae $(n=4$, PKUI 618-621) and Benthosema pterotum larvae $(n=4$, PKUI 614-617)

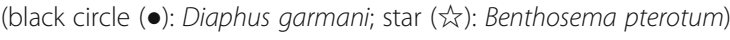


(2018). Morphometric characters included total length (TL), standard length (SL), body depth (BD), head depth $(\mathrm{HD})$, head length $(\mathrm{HL})$, preanus length $(\mathrm{PaL})$, eye diameter (ED), pre-dorsal fin length (PDFL) and pre-anal fin length (PAFL), which were observed under a stereomicroscope (SZH-16, Olympus, Japan) and then measured to the nearest $0.01 \mathrm{~mm}$ using an Image-Pro plus (ver. 2.0, Media Cybernetics) (Fig. 2). Meristic characters included the dorsal fin rays (D), anal fin rays (A), pectoral fin rays (P1), and pelvic fin rays (P2), which were stained with alizarin red $\mathrm{S}$ for counting under a stereomicroscope (SZH-16, Olympus, Japan). Each stage of larval development was sketched using a camera lucida attached to the stereomicroscope.

\section{Molecular analysis}

Total DNA was extracted from eyeballs removed from the right side of the larvae using $150 \mu \mathrm{L}$ Chelex 100 resin (Bio-Rad Laboratories, USA). The mitochondrial 16S rRNA region was amplified using the primers 5 '-CGC CTG TTT ATC AAA AAC AT-3' and 3'-CCG GTC TGA ACT CAG ATC ACG T-5' (Ivanova et al. 2007). The polymerase chain reaction (PCR) conditions were as follows: initial denaturation at $95^{\circ} \mathrm{C}$ for $11 \mathrm{~min} ; 35$ cycles of denaturation at $94{ }^{\circ} \mathrm{C}$ for $1 \mathrm{~min}$, annealing $52^{\circ} \mathrm{C}$ for 1 min, extension at $72^{\circ} \mathrm{C}$ for $1 \mathrm{~min}$; and a final extension at $72{ }^{\circ} \mathrm{C}$ for $5 \mathrm{~min}$. The same conditions were used for PCR analysis of $B$. pterotum, except that the annealing temperature was $54^{\circ} \mathrm{C}$. The sequences were aligned using ClustalW in the program BioEdit (ver. 7.0.5.3; Hall 1999), and genetic distances were calculated using the Kimura 2-parameter model (Kimura 1980) using Mega $\mathrm{X}$ (ver. 10.0.5). The genetic relationships were analyzed by constructing a neighbor-joining tree using Mega $\mathrm{X}$ (ver. 10.0.5) with 1000 bootstrap replications. The $16 \mathrm{~S}$ rRNA sequences of D. garmani (KR231737) and B. pterotum (JX133756) were also obtained from the National Centre for Biology Information database to compare eight specimens of Myctophidae larvae between the two species. The $16 \mathrm{~S}$ rRNA sequence of $B$. pterotum and $D$. garmani used in this study was assigned the following registration number from NCBI(MT242581-242587).

\section{Results}

\section{Molecular identification}

A $479 \mathrm{bp}$ of $16 \mathrm{~S}$ rRNA sequence was obtained from each of the four Myctophidae larvae for comparison with the sequence from adults of the candidate species $D$. garmani (KR231737). The genetic distances ranged from 0.6 to $0.8 \%$, indicating close consistency. We also compared the 16S rRNA gene sequences of the four B. pterotum larvae with that of the adult B. pterotum (JX133756) and found complete consistency, with a genetic distance of $0 \%$. The D. garmani larvae, juveniles, and adult were clearly separated from the four Diaphus spp. and $B$. pterotum in the neighbor joining tree (Fig. 3).

\section{Morphological features \\ Diaphus garmani Gilbert, 1906 (Fig. 4) (new Korean name: Gal-ma-ni-sat-bi-neul-chi)}

Diaphus garmani Gilbert, 1906: 258 (type locality: Cuba, western Atlantic) Masuda et al. 1984: 74; Hulley 1986: 291; Nakabo 2013: 473; Okiyama 2014: 336

Materials examined: PKUI 618, one specimen, 6.01 $\mathrm{mm}$ in standard length (SL), $32^{\circ} 99.61^{\prime} \mathrm{N}, 127^{\circ} 05.18^{\prime} \mathrm{E}$, southern Jejudo Island, 24 June 2017, Bongo net; PKUI 619 , one specimen, $7.50 \mathrm{~mm} \mathrm{SL}, 32^{\circ} 99.61^{\prime} \mathrm{N}, 127^{\circ}$ 05.18' E, southern Jejudo Island, 24 June 2017, Bongo

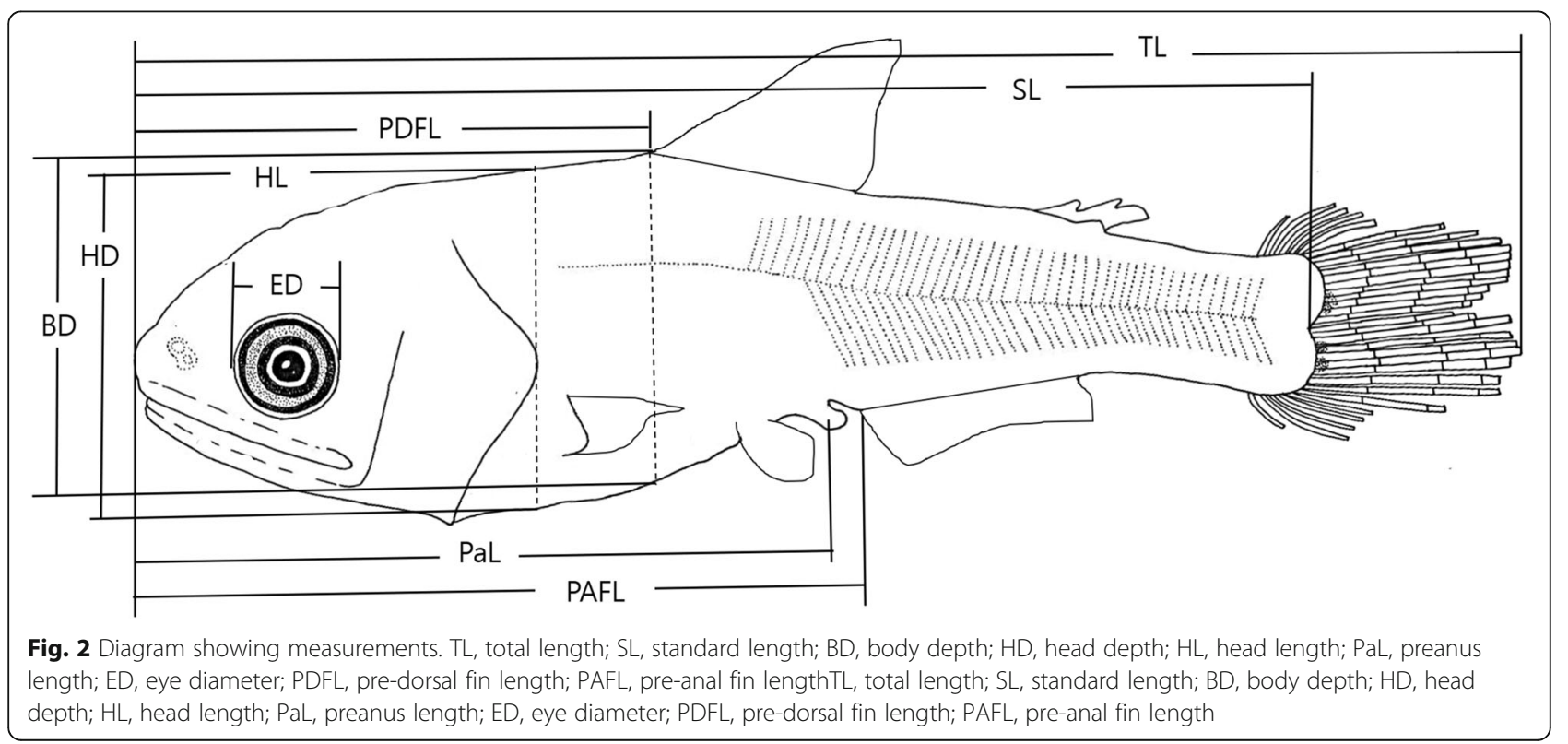




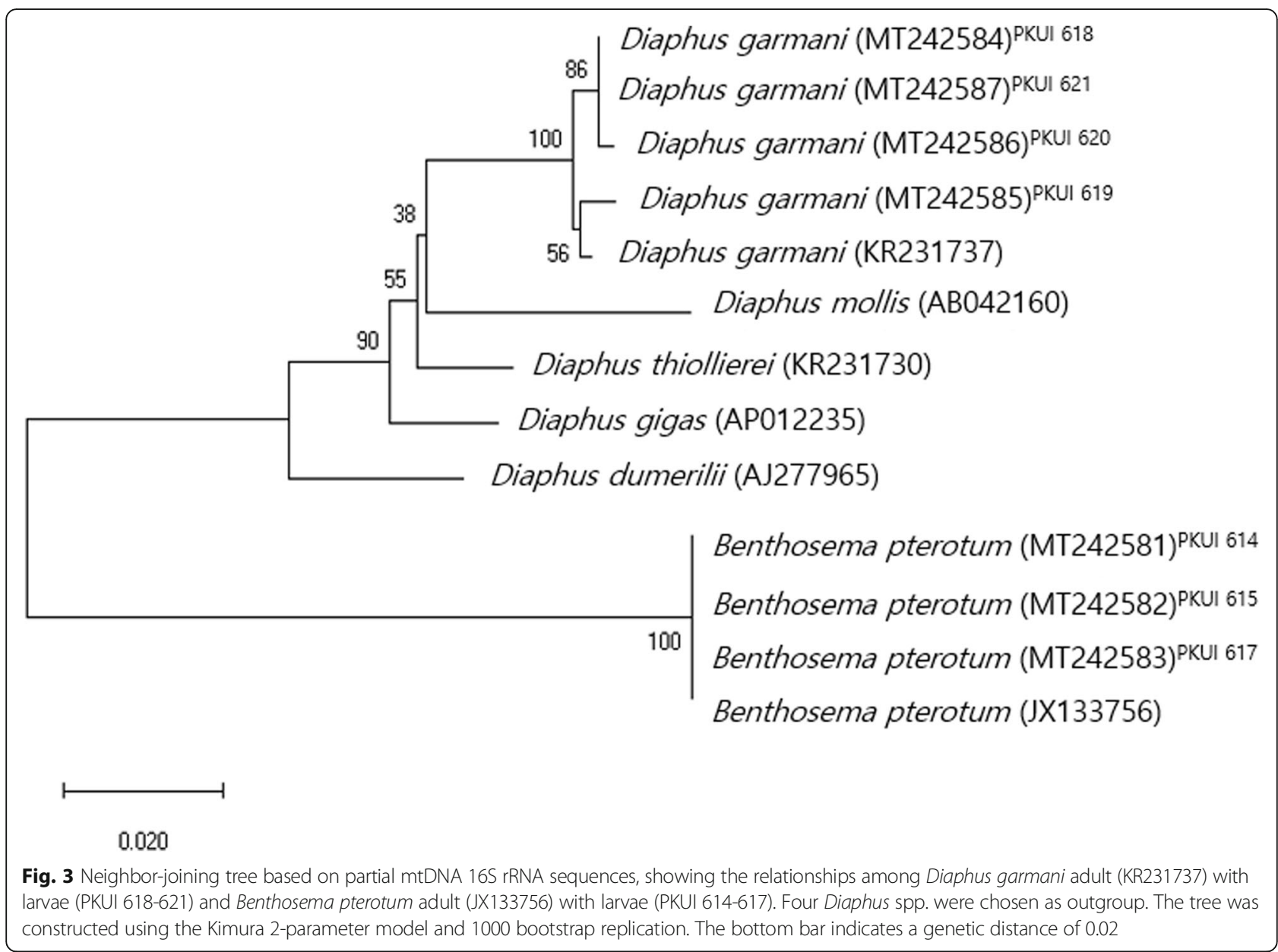

net; PKUI 620, one specimen, $7.72 \mathrm{~mm} \mathrm{SL}, 32^{\circ} 99.61^{\prime} \mathrm{N}$, $127^{\circ}$ 05.18' E, southern Jejudo Island, 24 June 2017, Bongo net; PKUI 621, one specimen, $9.62 \mathrm{~mm} \mathrm{SL}, 32^{\circ}$ 99.61' N, $127^{\circ} 05.18^{\prime} \mathrm{E}$, southern Jejudo Island, 24 June 2017, Bongo net.

The $6.01 \mathrm{~mm}$ standard length (SL) post-flexion larva of D. garmani (Fig. 4a) has large eyes with a pair of small nostrils situated in front. The mouth is large and slopes, with the rear end of the upper jaw reaching the posterior rim of the eye. There is a row of small sharp teeth in the jaws. The anus is positioned slightly behind the middle of the body. The end of the operculum tapers to a triangular shape. The myomeres show a clear $\mathrm{M}$ shape. $\mathrm{Br}_{2}$ photophores are found on the middle part of the lower jaw, and only a trace of $\mathrm{PO}_{5}$ photophore remain in front of the pelvic fin. The larva has an adipose fin, 13 dorsal fin rays, 14 anal fin rays, nine pectoral fin rays, and seven pelvic fin rays (Table 1). A few melanophores are present on the opercular organ, a series of three melanophores on the ventral side, one star-shaped melanophore on the anus, and one large dot-shaped melanophore at the posterior end of the anal fin base.
The $7.56 \mathrm{~mm}$ SL post-flexion larva of D. garmani (Fig. 4b) has a heavier head. $\mathrm{Br}_{2}$ photophores are observed on the middle part of the lower jaw, a line of $\mathrm{PO}_{1235}$ photophores is arranged along the ventral side of the abdominal cavity, and a raised $\mathrm{PO}_{4}$ photophore is situated between $\mathrm{PO}_{3}$ and $\mathrm{PO}_{5}$. A $\mathrm{PVO}_{12}$ photophore is observed between the base of the opercular organ and the pectoral fin, a $\mathrm{VO}_{1}$ photophore on the base of the pelvic fin, and $\mathrm{VO}_{45}$ photophores on the anus. There are 14 dorsal fin rays, 15 anal fin rays, 10 pectoral fin rays, and 8 pelvic fin rays (Table 1). The occurrence of melanophores is similar to that of the $6.01 \mathrm{~mm} \mathrm{SL}$ larva, but with the addition of two star-shaped melanophores in front of the pectoral fin and one and two on the upper and lower lobes, respectively, of the caudal fins.

The $7.72 \mathrm{~mm}$ SL juvenile of D. garmani (Fig. 4c) has a sharper snout than that at the previous stage, with the anus shifted forward toward the head. $\mathrm{Br}_{123}$ photophores are arranged in a line in the lower jaw. $\mathrm{OP}_{2}$ is recognized in the opercular organ under the eye. PLO is situated posterior to the operculum between the lateral line and pectoral fin. $\mathrm{PO}_{1235}$ photophores are aligned in the 

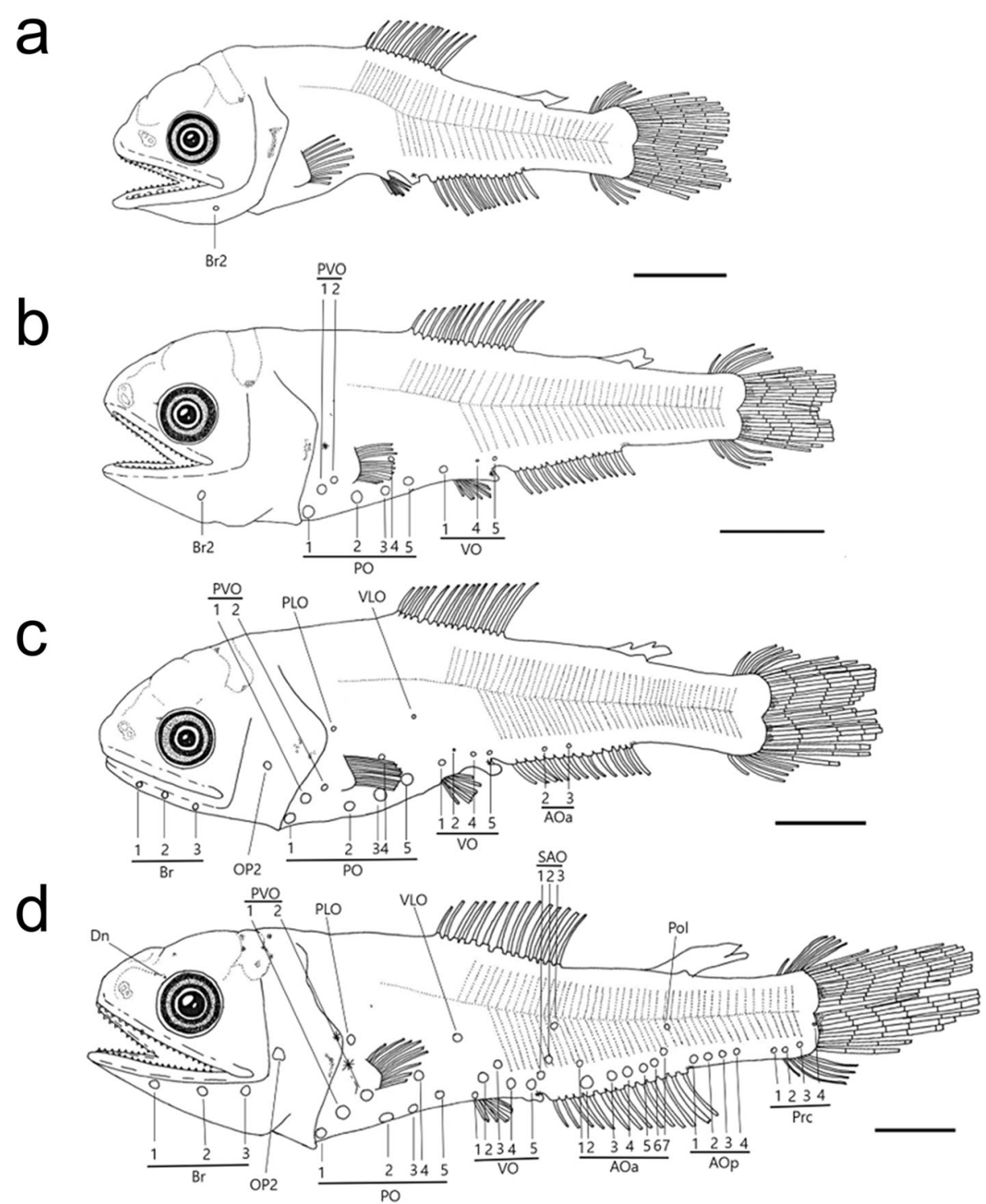

Fig. 4 Morphological development of Diaphus garmani (a post-flexion stage, PKUI 618, 6.01 mm SL; b post-flexion stage, PKUI 619, 7.56 mm SL; c juvenile stage, PKUI 620, 7.72 mm SL; d juvenile stage, PKUI 621, $9.62 \mathrm{~mm} \mathrm{SL}$ ). AOa, anterior anal organs; AOp, posterior anal organs; Br, branchiostegal organs; Dn, dorsonasal organ; OP, opercular organs; PLO, suprapectoral organ; PO, pectoral organs; Pol, postero-lateral organ; Prc, precaudal organs; PVO, subpectoral luminous glands; SAO, supraanal organs; VLO, supraventral organ; VO, ventral organs. Scale bars indicate $1.0 \mathrm{~mm}$

Table 1 Number of dorsal (D), anal (A), pectoral (P1), and pelvic (P2) fin rays of Diaphus garmani

\begin{tabular}{llllll}
\hline Voucher number & D & A & P1 & P2 & Stage \\
\hline PKUI 618 & 13 & 14 & 9 & 7 & Post-flexion \\
PKUI 619 & 14 & 15 & 10 & 8 & Post-flexion \\
PKUI 620 & 14 & 15 & 13 & 8 & Juvenile \\
PKUI 621 & 14 & 14 & - & 8 & Juvenile \\
\hline
\end{tabular}

abdominal cavity. The $\mathrm{PO}_{4}$ photophore is raised between $\mathrm{PO}_{3}$ and $\mathrm{PO}_{5}$. The $\mathrm{PVO}_{12}$ photophore is situated obliquely between the base of the opercular organ and the pectoral fin. VLO is raised slightly from the middle between the base of the pelvic fin and the lateral line. $\mathrm{VO}_{145}$ photophores are arranged in a line behind the pelvic fin. The $\mathrm{VO}_{2}$ photophore is raised between $\mathrm{VO}_{1}$ and $\mathrm{VO}_{4} \cdot \mathrm{AOa}_{23}$ photophores are lined on the anal fin. There are 14 dorsal fin rays, 15 anal fin rays, 13 pectoral fin rays, and 8 pelvic fin rays (Table 1). Several melanophores are present on the opercular organ. Two star-shaped melanophores are aligned on the abdominal cavity. One star- 
shaped melanophore is present on the anus. A dot-shaped melanophore is present at the end of the anal fin base. There are one and two melanophores dotted on the upper and lower lobes, respectively, of the caudal fin.

The $9.62 \mathrm{~mm}$ SL juvenile of D. garmani (Fig. 4d) has a similar morphology to that of the previous developmental stage. $A D_{n}$ photophore is present in front of the eye. $\mathrm{Br}_{123}$ photophores are lined in the lower jaw. $\mathrm{A} \mathrm{OP}_{2}$ is located under the eye. $\mathrm{PO}_{1235}$ photophores are arranged in a line in the abdominal cavity. $\mathrm{PO}_{4}$ is raised between $\mathrm{PO}_{3}$ and $\mathrm{PO}_{5}$. The $\mathrm{PVO}_{12}$ photophore is situated obliquely between the base of the opercular organ and the pectoral fin. PLO is situated between the base of the pectoral fin and the lateral line. VLO is raised slightly from the middle between the base of the pelvic fin and the lateral line. The $\mathrm{VO}_{145}$ photophores are arranged in a line behind the pelvic fin. The $\mathrm{VO}_{23}$ photophores are situated obliquely between $\mathrm{VO}_{1}$ and $\mathrm{VO}_{4}$. The $\mathrm{SAO}_{123}$ photophores are gradually raised behind $\mathrm{VO}_{5} \cdot \mathrm{AOa}_{1}$ is slightly raised from the anal fin base and follows the line of $\mathrm{AOa}_{23456}$ photophores arranged along the anal fin base. $\mathrm{AOa}_{7}$ is raised more. Pol is near the lateral line at the end of the anal fin base. The $\mathrm{AOp}_{1234}$ photophores are arranged in a line along the caudal peduncle base behind the anal fin base. A line of $\operatorname{Prc}_{123}$ photophores is near the caudal peduncle, and $\mathrm{Prc}_{4}$ is observed under the lateral line of the caudal peduncle. There are 14 dorsal fin rays, 14 anal fin rays, and 8 pelvic fin rays (Table 1). Of the melanophores, one is observed above the left side of the eye, a few are recognized on the top of the head and the opercular organ with two starshaped melanophores nearby. One melanophore is dotted on the anus, and one on the upper lobe and two dotted on the lower lobe of the caudal fin.

Benthosema pterotum (Alcock, 1890) (Fig. 5) (Korean name: Git-bi-neul-chi)

Scopelus pterotus Alcock, 1890: 217 (type locality: Madras coast, India)

Benthosema pterotum: Masuda et al. 1984: 65; Hulley 1986: 285; Nakabo 2013: 451; Okiyama 2014: 364.

Materials examined: PKUI 614, one specimen, 9.81 $\mathrm{mm} \mathrm{SL}, 34^{\circ} 83.28^{\prime} \mathrm{N}, 129^{\circ} 10.75^{\prime}$ E, eastern Korea Strait, 9 Dec 2018, Bongo net; PKUI 615, one specimen, 5.75 $\mathrm{mm}$ in standard length (SL), $32^{\circ} 68.40^{\prime} \mathrm{N}, 123^{\circ} 88.52^{\prime} \mathrm{E}$, western Jejudo Island, 16 Sep 2018, Bongo net; PKUI 616 , one specimen, $7.27 \mathrm{~mm} \mathrm{SL}, 33^{\circ} 09.68^{\prime} \mathrm{N}, 126^{\circ}$ 38.57' E, East Sea, 9 Dec 2018, Bongo net; PKUI 617, one specimen, $8.07 \mathrm{~mm} \mathrm{SL}, 37^{\circ} 18.53^{\prime} \mathrm{N}, 129^{\circ} 67.90^{\prime} \mathrm{E}$, East Sea, 20 July 2018, Bongo net.

The $5.75 \mathrm{~mm}$ SL post-flexion larva of B. pterotum (Fig. 5a) has a small body depth and large head depth, with the head depth decreasing from the nape. At this stage of development, the larva has large eyes and a sharp snout. The anus is positioned slightly behind the middle of the body. $\mathrm{A} \mathrm{Br}_{2}$ photophore is found in the lower jaw under the eye and $\mathrm{Bu}$ under the rear of the eye. The adipose fin is present. There are 10 dorsal fin rays, 14 anal fin rays, 11 pectoral fin rays, and 7 pelvic fin rays (Table 2 ). Observed melanophores include one on the end of the lower jaw snout, a line of melanophores in the lower jaw, one on the central upper part of the gut, many melanophore dots around the anus, and a line of very short, indistinct melanophores on the anal fin.

The $7.27 \mathrm{~mm}$ SL juvenile of B. pterotum (Fig. 5b) has a Dn photophore in front of the eye, $\mathrm{Br}_{2}$ on the lower jaw under the eye, and $\mathrm{Bu}$ under the rear of the eye. There are 12 dorsal fin rays, 18 anal fin rays, 11 pectoral fin rays, and 8 pelvic fin rays (Table 2). Observed melanophores include one on the end of the lower jaw, one around the nostrils, a line of four melanophores at the base of the opercular organ, in addition to irregularly distributed small dots of melanophores, and a few on the anus. During this stage of development, existing melanophores disappear from the central anus and central muscle of the anal fin.

The $8.07 \mathrm{~mm}$ SL juvenile of B. pterotum (Fig. 5c) has a Dn photophore in front of the eye, $\mathrm{Br}_{2}$ on the lower jaw under the eye, and $\mathrm{Bu}$ under the rear of the eye. There are 12 dorsal fin rays, 18 anal fin rays, 11 pectoral fin rays, and 8 pelvic fin rays (Table 2). Observed melanophores include one at the tip of the lower jaw snout, one under the nostrils, a line of dark dots on the base of the opercular organ, and a large melanophore dot on the anus.

The $9.81 \mathrm{~mm}$ SL juvenile of B. pterotum (Fig. 5d) has a Dn photophore in front of the eye, $\mathrm{Br}_{2}$ on the lower jaw under the eye, $\mathrm{Cp}$ on the opercular organ, a series of $\mathrm{PO}_{1234}$ photophores followed by a raised $\mathrm{PO}_{5}$ in the isthmus, $\mathrm{PVO}_{1}$ in front of the base of the pectoral fin behind the operculum organ, $\mathrm{VO}_{1}$ under the pelvic fin followed by a raised $\mathrm{VO}_{2}, \mathrm{AOa}_{12}$ on the anal fin, and $\mathrm{Prc}_{2}$ below the lateral line of the anal fin. There are 10 (?) dorsal fin rays, 18 anal fin rays, 11 pectoral fin rays, and 8 pelvic fin rays (Table 2). Observed melanophores include a series of dots under the operculum organ, one dot on the anus, one melanophore each on the upper and lower lobes of the base of the caudal fin.

\section{Discussion}

We performed a molecular identification of Myctophidae larvae and juveniles collected in the waters around Jeju Island and the East Sea in June 2017 and found that four of the larvae had $99.2-99.4 \%$ identity to the sequence of a $D$. garmani adult and the other four larvae $100 \%$ identity to the sequence of a B. pterotum adult. Diaphus garmani has not been recorded in Korea, and its morphological features and measurements according to developmental stage obtained in this study were 

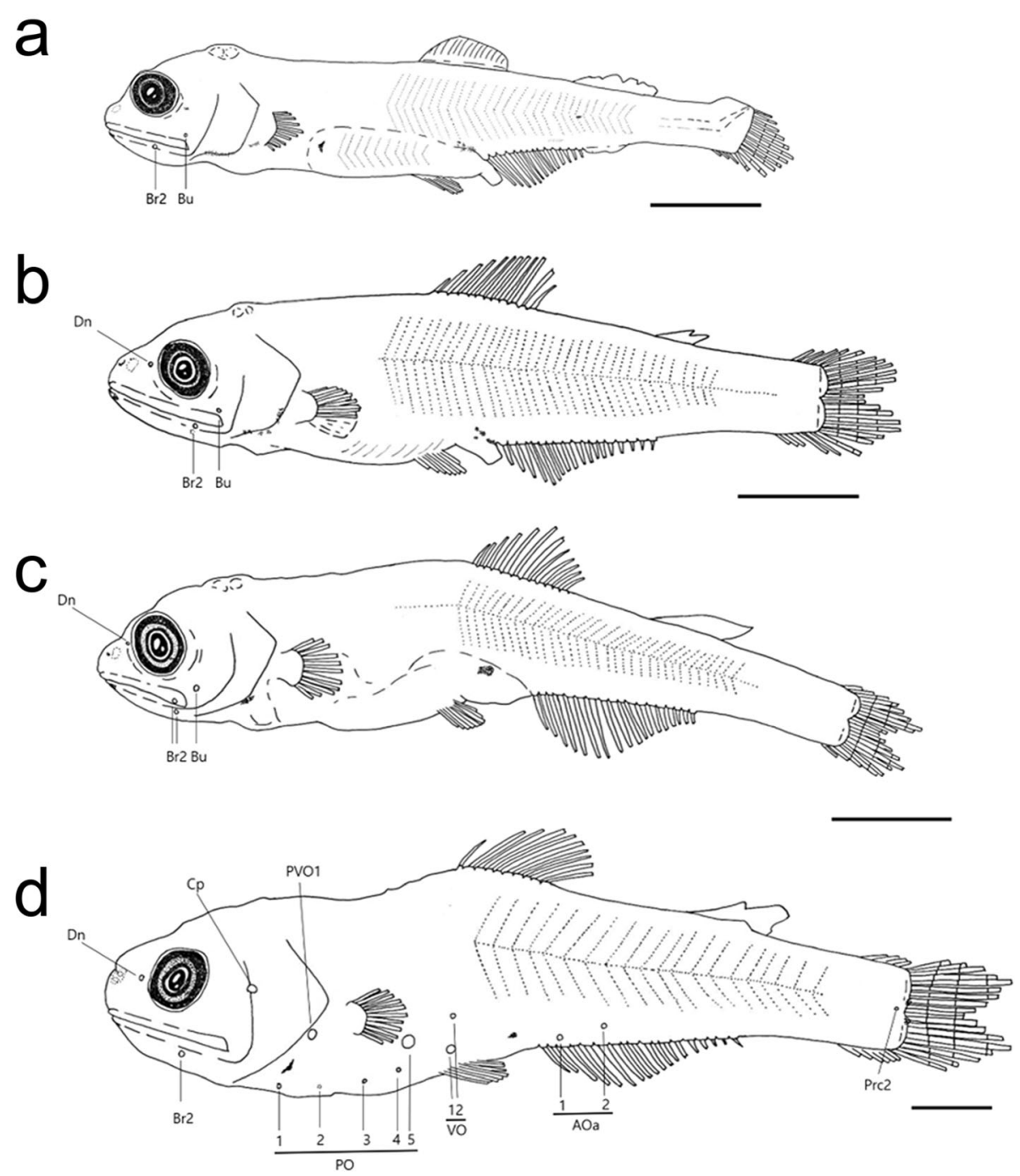

Fig. 5 Morphological development of Benthosema pterotum (a post-flexion stage, PKUI 615, 5.75 mm SL; b juvenile stage, PKUI 616, 7.27 mm SL; c juvenile stage, PKUI 617, 8.07 mm SL; d juvenile stage, PKUI 614, $9.81 \mathrm{~mm} \mathrm{SL).} \mathrm{AOa,} \mathrm{anterior} \mathrm{anal} \mathrm{organs;} \mathrm{Br,} \mathrm{branchiostegal} \mathrm{organs;} \mathrm{Bu,} \mathrm{buccal}$ organ; CP, cheek photophore; Dn, dorsonasal organ; PO, pectoral organs; Prc, precaudal organs; PVO, subpectoral luminous glands; VO, ventral organs. Scale bars indicate $1.0 \mathrm{~mm}$

found to be generally consistent with previous reports (Gilbert 1906; Kawaguchi and Shimizu 1978; Sassa et al. 2003; Richards 2006; Bineesh et al. 2010; Okiyama 2014). Okiyama (2014) suggested that the completion of metamorphosis and photophore development occurs later in B. pterotum (12-13 mm SL) than in D. garmani

Table 2 Number of dorsal (D), anal (A), pectoral (P1), and pelvic (P2) fin rays of Benthosema pterotum

\begin{tabular}{llllll}
\hline Voucher number & D & A & P1 & P2 & Stage \\
\hline PKUI 615 & 10 & 14 & 11 & 7 & Post-flexion \\
PKUI 616 & 12 & 18 & 11 & 8 & Juvenile \\
PKUI 617 & 12 & 18 & 11 & 8 & Juvenile \\
PKUI 614 & 10 (?) & 18 & 11 & 8 & Juvenile \\
\hline
\end{tabular}

(11 mm SL), which is consistent with our results. In this study, a juvenile D. garmani (PKUI 621, $9.62 \mathrm{~mm} \mathrm{BL}$ ) developed $\mathrm{AOa}_{1-7}$. This result is consistent with that in the original descriptive paper (Gilbert 1906), but differs from the results of Nakabo (2013) and Bineesh et al. (2010) which described only $\mathrm{AOa}_{1-6}$. In addition, D. garmani juveniles in this study had a $\operatorname{Prc}_{4}$ photophore under the lateral line inside of the caudal fin, which is consistent with Bineesh et al. (2010) but clearly different than that present under the lateral line outside of the caudal fin from Nakabo (2013). It is thought that the discrepant results for the $\mathrm{AOa}$ photophores are due to individual variations, but further study will be needed with regard to the Prc4 photophore location. The species D. garmani and B. pterotum share the characteristics of 
body shape, eye size, and photophore arrangement, but the two species can be differentiated by the photophore development process and relative growth of individuals of similar size. In terms of photophore development, $B$. pterotum first develops Dn in front of the eye, whereas $D$. garmani first develops $\mathrm{OP}_{2}$ at the base of the opercular organ. B. pterotum has $\mathrm{Bu}$ under the right eye and Cp on the isthmus, which are not present in D. garmani. The two species can also be differentiated by the position of the PO photophores; D. garmani has $\mathrm{PO}_{4}$ at the highest raised position, whereas $B$. pterotum has $\mathrm{PO}_{5}$ as the highest PO photophore. The arrangement of $\mathrm{VO}$ photophores can also clearly differentiate the two species: $\mathrm{VO}_{3}$ is located at the top in D. garmani versus $\mathrm{VO}_{2}$ in B. pterotum. $\mathrm{AOa}_{1}$ is positioned higher than the other AOa photophores in D. garmani, whereas the AOa photophores are arranged horizontally in B. pterotum.

In the adult stage, the two species can be clearly identified by the number of Prc photophores: four in $D$. garmani and two in B. pterotum (Nakabo 2013). We also found four Prc photophores in D. garmani and one in $B$. pterotum. Comparing the body ratios of the two species at each developmental stage, the ratios of head depth, head length, preanus length, eye diameter, and pre-anal fin length to SL differentiated the two species (Fig. 6a-e), except the ratio of pre-dorsal fin length to SL (Fig. 6a-f). Okiyama (2014) suggested that in D. garmani, the ratios of pre-anal fin length, head length, and body depth to SL

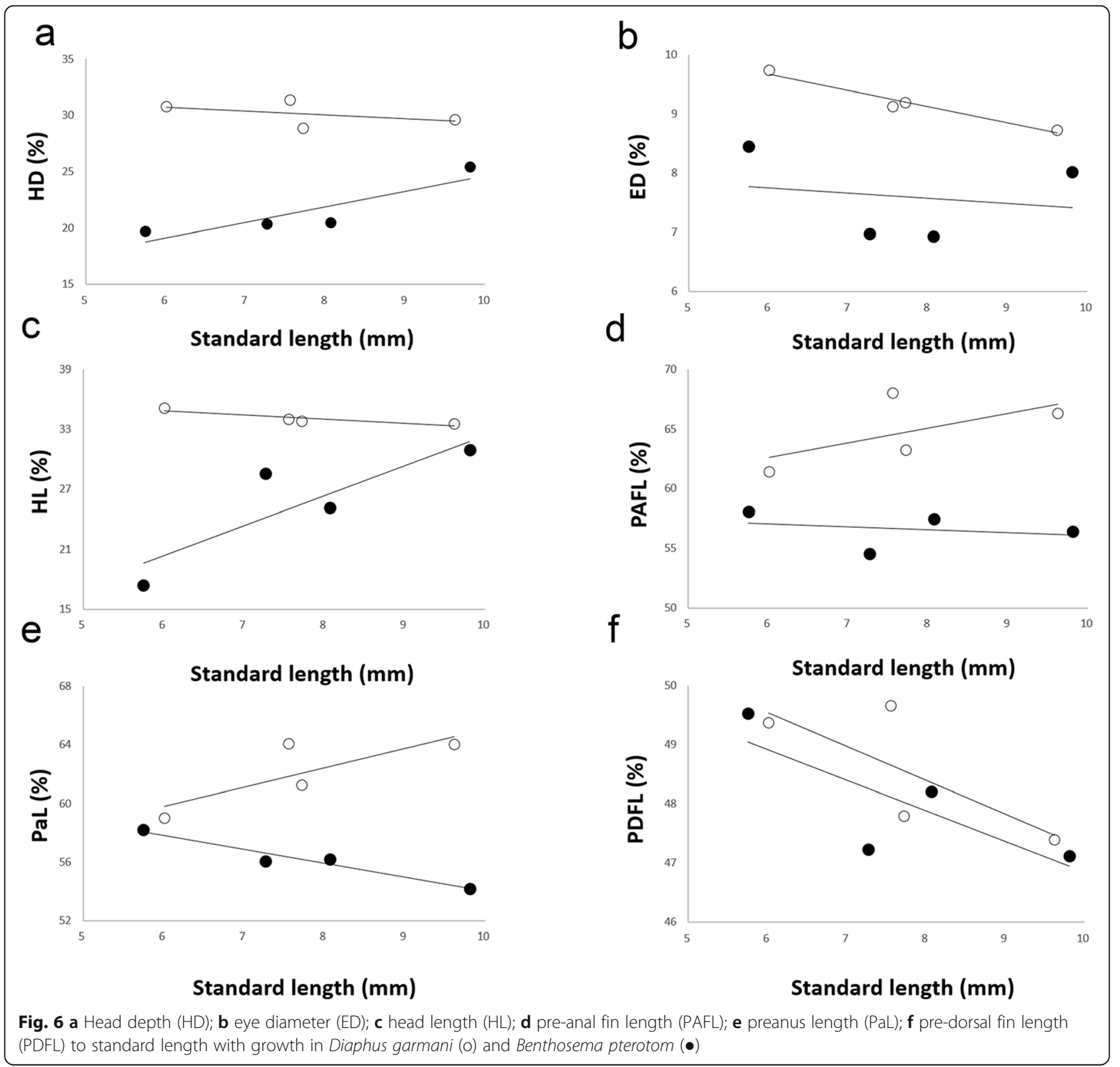


increase linearly until the larvae grow to $7 \mathrm{~mm} \mathrm{SL}$, after which the ratios gradually decrease until they reach the juvenile stage. In contrast to that previous study, we showed that the pre-anal fin length increased with SL in D. garmani, but with no change in head length. This result may be related to the trivial difference in genetic distance (0.6$0.8 \%$ ) in terms of the 16S rRNA sequence between Japanese D. garmani adults and the D. garmani larvae collected in Korean waters, which requires further study.

\section{Conclusions}

Based on mitochondrial DNA 16S rRNA sequences, two larvae and two juveniles were identified as Diaphus garmani, which is the first record in Korean waters. Among myctophid species previously recorded in Korea, Benthosema pterotum seems to be very similar to $D$. garmani in external morphology. The two species were distinguished by melanophores in the abdominal cavity (absent in D. garmani vs. present in B. pterotum) and the development of photophores (developed in $D$. garmani vs. rudimentary in B. pterotum) when shorter than $10.0 \mathrm{~mm}$ standard length. We propose a new Korean name Gar-ma-ni-sat-bi-neul-chi, a combination of the specific name garmani and the Korean name of the family Myctophidae Sat-bi-neul-chi.

\section{Acknowledgements}

We are grateful to crews of research vessel of NIFS for their sampling and anonymous reviewers for their valuable comments.

\section{Authors' contributions}

$H L L$ and JKK conducted the research, analyzed the materials, and prepared the draft manuscript. JKK, HJY, and JNK designed and directed the study and finalized the manuscript. All authors read and approved the final manuscript.

\section{Funding}

This work was supported by a grant from the National Institute of Fisheries Science (R2020021) and also supported by the Marine Fish Resource Bank of Korea (No. 20170431) under the Ministry of Oceans and Fisheries, Korea.

\section{Availability of data and materials}

All datasets analyzed during the current study are available from the corresponding author on reasonable request.

\section{Ethics approval and consent to participate}

Not applicable.

\section{Consent for publication}

Not applicable.

\section{Competing interests}

The authors declare that they have no competing interests.

\section{Author details}

'Department of Marine Biology, Pukyong National University, Busan 48513, Korea. ${ }^{2}$ Fisheries Resources Research Center, National Institute of Fisheries Science, Tongyeong 53064, Korea.
Received: 10 October 2019 Accepted: 31 May 2020

Published online: 14 July 2020

\section{References}

Alcock AW. Annals and Magazine of Natural History. 6rd ed. London: Taylor and Francis; 1890. p. 217-18.

Bineesh KK, Sebastine M, Akhilesh KV, Pillai NGK. First record of the Garman's lanternfish Diaphus garmani (Family: Myctophidae) from Indian waters. J Mar Biol Assoc India. 2010;52:109-12.

Fricke R, Eschmeyer WN, Fong JD. Catalog of Fishes: Genera, Species, References. California Academy of Sciences; 2017. http://researcharchive.calacademy.org/ research/ichthyology/catalog/fishcatmain.asp. Accessed 17 Apr 2015.

Froese R, Pauly D. FishBase; 2019. http://www.fishbase.org. Accessed 31 Dec 2018.

Gilbert $\mathrm{CH}$. Certain scopelids in the collection of the Museum of Comparative Zoölogy. Bull Mus Comparative Zool. 1906;46:258-9.

Hall TA. BioEdit: A user-friendly biological sequence alignment editor and analysis program for windows 95/98/ NT. Nucleic Acids Symp. 1999;41:95-8.

Hulley PA. Order Myctophiformes. In: Smith MM, Heemstra PC, editors. Smiths' Sea Fishes. Grahamstown; 1986. p. 282-322.

Ivanova NV, Zemlak TS, Hanner RH, Hebert PDN. Universal primer cocktails for fish DNA barcoding. Mol Ecol Notes. 2007;7:544-8.

Javadzadeh N, Valinassab T, Fatemi MR. Morphometric features of mesopelagic lanternfish, Diaphus garmani, from the Oman Sea, Iran: first record. World Appl Sci J. 2012;17:489-93.

Kawaguchi K, Shimizu H. Taxonomy and distribution of the lanternfishes, genus Diaphus (Pisces, Myctophidae) in the western Pacific, eastern Indian Oceans and the southeast Asian Seas. Bull Ocean Res Inst Univ Tokyo. 1978;10:1-145.

Kim S, Cha SS, Kim C-H, Oh J, Lee Y-H, Kim W-S. The composition of the developmental stages of Maurolicus japonicus (Sternoptychidae, Stomiiformes) eggs in the western Korea Strait. Korean J Ichthyol. 2007;19: 378-86.

Kim S, Yoo JM. Distribution of eggs and larvae of Maurolicus muelleri in the thermal front of the Korea Strait. Korean J Ichthyol. 1999;11:62-71.

Kimura M. A simple method for estimating evolutionary rates of base substitutions through comparative studies of nucleotide sequences. J Mol Evol. 1980;16:111-20.

Lee SJ, Kim JK. New record of juvenile Sigmops gracilis (Pisces: Gonostomatidae) from Jeju Island, Korea, revealed by DNA barcoding. Fish Aquat Sci. 2013;16:45-8.

MABIK (Marine Biodiversity Institute of Korea). National List of Marine Species. Seocheon: Namu Press; 2019. p. 23.

Martin RP, Olson EE, Girard MG, Smith WL, Davis MP. Light in the darkness: New perspective on lanternfish relationships and classification using genomic and morphological data. Mol Phylogenet Evol. 2018;121:71-85.

Masuda H, Amaoka K, Araga C, Uyeno T, Yoshino T. The fishes of the Japanese Archipelago. Japan: Tokai Univ Press, Tokyo; 1984. p. 74.

Mini R, James PSBR. Distribution and abundance of lanternfishes of the family Myctophidae in the EEZ on India. In: Mathew KJ, editor. Proceedings of the second workshop on scientific results of FORV Sagar Sampada. Cochin; 1990. p. 285-90.

Moser HG, Ahlstrom EH. Myctophidae: Lanternfishes. In: Moser HG, editor. The early stages of fishes in the California Current Region, vol. 33: CalCOFI Atlas; 1996. p. 387-475

Nafpaktitis BG. Systematics and distribution of lanternfishes of the genera Lobianchia and Diaphus (Myctophidae) in the Indian Ocean. Nat Hist Mus Los Angeles County Sci Bull. 1978;30:1-92.

Nafpaktitis BG. Western Indian Ocean: Myctophidae. Vol 3. Depart Biol Sci, Univ Southern California, Univ Park, Los Angeles, USA; 1982.

Nafpaktitis BG, Robertson DA, Paxton JR. Four new species of the lanternfish genus Diaphus (Myctophidae) from the Indo-Pacific. New Zealand J Mar Fresh. 1995:29:335-44.

Nakabo T. Fishes of Japan with Pictorial Keys to the Species. 3rd ed. Japan: Tokai Univ Press; 2013. p. 444-73.

Nelson JS, Grande TC, Wilson MV. Fishes of the World. 5th ed. Hoboken: Wiley; 2016. p. 223-5.

Okiyama M. An Atlas of the Early Stage Fishes in Japan. 4rd ed. Tokyo: Tokai Univ Press; 2014. p. 327-83.

Ozawa T. Early life history of the family Myctophidae in the Ocean off Southern Japan. In: Ozawa T, editor. Studies on the oceanic ichthyoplankton in the western North Pacific. Hukuoka: Kyushu Univ Press; 1986. p. 114-87. 
Park G-H, Kim J-K, Ji H-S, Choi J-H. Molecular identification and morphological description of juveniles of the previously unrecorded species Notoscopelus japonicus (Tanaka, 1908) (Myctophidae) in Korean waters. Korean J Fish Aquat Sci. 2019:52(4):424-9.

Paxton JR, Ahlstrom EH, Moser HG. Myctophidae: Relationships. In: Moser HG, Richards WJ, Cohen DM, Fahay MP, Kendall AW, Richardson SL, editors. Ontogeny and Systematics of Fishes. Lawrence: Special Publication 1 of the American Society of Ichthyologists and Herpetologists; 1984. p. 239-44.

Richards WJ. Early stages of Atlantic fishes: an identification guide for the Western Central North Atlantic, Vol. I. Boca Raton: CRC Press; 2006. p. 473-580

Sassa C, Kawaguchi K, Loeb VJ. Early development of Diaphus garman (Myctophidae) in the transition region of the western North Pacific. Ichthyol Res. 2003;50:94-7.

Watanabe H, Moku M, Kawaguchi K, Ishimaru K, Ohno A. Diel vertical migrations of myctophid fishes (Family: Myctophidae) in the transitional waters of the western North Pacific. Fish Oceanogr. 1999;8:115-27.

\section{Publisher's Note}

Springer Nature remains neutral with regard to jurisdictional claims in published maps and institutional affiliations.

Ready to submit your research? Choose BMC and benefit from:

- fast, convenient online submission

- thorough peer review by experienced researchers in your field

- rapid publication on acceptance

- support for research data, including large and complex data types

- gold Open Access which fosters wider collaboration and increased citations

- maximum visibility for your research: over $100 \mathrm{M}$ website views per year

At BMC, research is always in progress.

Learn more biomedcentral.com/submissions 